\title{
Tubulin and Actin Topology during Zygote Formation of Saccharomyces cerevisiae
}

\author{
By JIŘÍ HAS̆EK, * IVAN RUPEŠ, JANA SVOBODOVÁ \\ AND EVA STREIBLOVÁ \\ Institute of Microbiology, Czechoslovak Academy of Sciences, Videñská 1083, 14220 Prague 4, \\ Czechoslovakia
}

(Received 5 May 1987; revised 22 July 1987)

\begin{abstract}
The topology of tubulin and actin during mating of Saccharomyces cerevisiae was analysed by fluorescence microscopy with the monoclonal anti-tubulin antibody Tu01 and rhodaminelabelled phalloidin. Preconjugatory cells displayed an asymmetric distribution of the microtubule and actin cytoskeleton and an overall polarization of the cells preceding cell fusion. Prior to karyogamy, the haploid spindle pole bodies were associated with abundant cytoplasmic microtubules. Budding zygotes revealed the same tubulin and actin patterns as vegetative cells. Treatment of the mating mixture with the microtubule inhibitor nocodazole $\left(10 \mu \mathrm{g} \mathrm{ml}^{-1}\right)$ did not prevent polarization and fusion of haploids, zygote formation and emergence of the first zygotic bud. In marked contrast, the migration of the nucleus in preconjugatory cells as well as nuclear migration and fusion within the zygotes was unequivocally blocked by the action of the drug. It is suggested that the problem of the morphogenesis of mating should be approached by considering interactions at the cell periphery.
\end{abstract}

\section{INTRODUCTION}

The mixing of haploid cells of Saccharomyces cerevisiae of opposite mating types leads to zygote formation involving several distinct morphogenetic steps. As described in the pioneering work of Hartwell (1973), cells of mating types a and $\alpha$ competent for cell fusion are unbudded and blocked just before the initiation of DNA replication. Mutual interactions of cells of opposite mating types are mediated by mating pheromones, the continued presence of which is necessary for cell fusion as well as for karyogamy (Thorner, 1981). However, the way in which the signal is transformed to control the spatial organization of the cells is still a matter of discussion (Davis \& Thorner, 1986). Electron microscopic observations indicate that microtubules participate in this process (Byers, 1981).

The aim of the present paper is to analyse the display of major cytoskeletal proteins tubulin and actin during mating using fluorescent staining with the monoclonal antibody Tu01 for $\alpha$ tubulin (Viklický et al., 1982 Dráber et al., 1985) and rhodamine-conjugated phalloidin for Factin (Wieland \& Govindan, 1974). We have concentrated on relevant features concerned with the topology of the cytoskeleton in the following events: (i) polarization of gametic cells induced under the influence of mating pheromones, (ii) cell fusion of appropriate mating partners, (iii) fusion of parental nuclei within zygotes, (iv) positioning of dividing nuclei within zygotes, and (v) development of zygotic buds. The functional implication of the presence of the cytoskeletal network in the above steps is addressed experimentally using nocodazole (Hoebecke et al., 1976), one of only a few agents that promote an almost complete disassembly of yeast microtubules (Pringle et al., 1986; Pillus \& Solomon, 1986; Hašek et al., 1986).

\footnotetext{
Abbreviations: DAPI, 4',6'-diamidino-2-phenylindole; MBC, methylbenzimidazole-2-yl carbamate; SPB,
} spindle pole body. 


\section{METHODS}

Strains. The following strains of $S$. ceretisiae were used: AH 215 (mating type a: kindly provided by Dr A. Hinnen), GRF 18 (mating type $\alpha$; kindly provided by Dr G. Fink), and CCY $21-4-59$ (a $\alpha$ diploid; kindly provided by Dr A. Svoboda).

Coniugation of cells. The cells were grown on YPG medium $[1 \%(w / v)$ peptone, $1 \%(w / v)$ yeast extract, $2 \%(w / v)$ glucose, pH 6.5] (Fink, 1970) to late exponential phase. After harvesting by centrifugation, cells of both mating types were washed with phosphate buffered saline (PBS: $0.14 \mathrm{M}-\mathrm{NaCl}, 2.7 \mathrm{~mm}-\mathrm{KCl}, 1.5 \mathrm{mM}-\mathrm{KH}_{2} \mathrm{PO}_{4}, 8.1 \mathrm{mM}-$ $\mathrm{Na}_{2} \mathrm{HPO}_{4}, \mathrm{pH} 7 \cdot 3$ ). The populations were resuspended in $3{ }_{\circ}^{\circ} \mathrm{YEG}$ medium (Bilinski et al., 1975) and mixed to a final concentration of about $10^{8}$ cells of each mating type per $\mathrm{ml}$. The mixture was cultivated on a reciprocal shaker at $25^{\circ} \mathrm{C}$ for $6 \mathrm{~h}$. In nocodazole experiments $10 \mu \mathrm{g}$ nocodazole $\mathrm{ml}^{-1}$ was added to $\mathrm{YEG}$ medium from stock solution of $2.5 \mathrm{mg}$ nocodazole $\mathrm{ml}^{-1}$ in dimethylsulphoxide.

Fixing and staining. Zygotes and cells were fixed with $3^{\circ}\left(w_{i} / v\right)$ formaldehyde (prepared from paraformaldehyde: Sigma) at $25^{\circ} \mathrm{C}$ for $2 \mathrm{~h}$ by adding $15^{\circ}$ formaldehyde in fixing buffer $\left[0.5 \mathrm{M}-\mathrm{KH}_{2} \mathrm{PO}_{+} .150 \mathrm{~mm}-\mathrm{EGTA}\right.$.

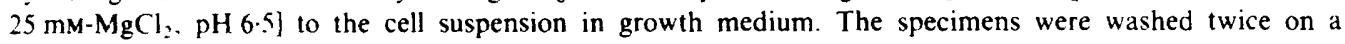
membrane filter and resuspended in $0.1 \mathrm{M}$-potassium phosphate buffer. pH 6.5. The cell wall was partially digested by a $30 \mathrm{~min}$ treatment with crude snail digestive juice (kindly provided by Dr Svoboda) added to the cell suspension $(1: 1, \mathrm{v} / \mathrm{v})$ in the presence of $1 \mathrm{~mm}$-phenylmethanesulphonyl fluoride. Digested cells were carefully washed with PBS and dried onto coverslips. Finally, the cells were permeabilized with cold methanol $\left(-20^{\circ} \mathrm{C}\right)$ for $20 \mathrm{~min}$

Anti-tubulin staining with the monoclonal antibody Tu01 (Viklický et al.. 1982) was done as described elsewhere (Hašek et al., 1986). Coverslips were mounted in glycerol/propylgallate (Giloh \& Sedat, 1981) in order to diminish the quenching of fluorescence.

To stain filamentous actin, fixed cells with partially digested cell walls were treated with $20 \mu \mathrm{g}$ rhodaminelabelled phalloidin $\mathrm{ml}^{-1}$ (Rh-phalloidin: a generous gift of $\operatorname{Dr} \mathrm{T}$. Wieland) in $1 \%(\mathrm{v} / \mathrm{v})$ Triton X-100/PBS for $15 \mathrm{~min}$. After washing with PBS, the specimens were mounted in glycerol/p-phenylendiamine (Johnson \& de C. Nogueira Araujo, 1981) to prevent bleaching of the rhodamine. Both mounting media contained $2 \mu \mathrm{g}$ DAPI ml ${ }^{-1}$ for staining DNA (Williamson \& Fenell. 1975). Calcofluor (primulin) staining was done as described previously (Streiblová, 1970, 1983).

Specimens were examined by epifluorescence microscopy using a JenaLumar fluorescence microscope (Zeiss Jena, GDR) using appropriate filter systems. Photographs were taken on Kodak Tri-X pan film processed in an OR WO A49 developer

\section{RESULTS}

\section{Tuhulin and actin during the budding process}

In unbudded cells of $S$. cererisiae, actin was organized as filaments and dots distributed primarily in the peripheral cytoplasm beneath the plasma membrane (not shown). The sites of emerging buds showed conspicuous accumulation of actin dots whereas actin filaments formed a distinct basket around the nucleus (Fig. $1 a$ ). Cells with emerging buds displayed duplicated but unseparated SPBs. Bundles of cytoplasmic microtubules appeared to emanate from the connection between duplicated SPBs toward the budding site and through the cytoplasm (Fig. (b).

We next examined the display of tubulin and actin throughout the budded portion of the cell cycle. It appeared that continuous association between the SPBs establishing the poles of the developing spindle and the periphery of the mother and daughter cells persisted until cytokinesis (Figs $1 c, d$ ). Examination of actin-specific staining during the transitional stages of bud expansion revealed actin filaments extending from the tip of the growing bud into the mother cell (Fig. 1e). Finally, in cells in which the bud had grown to its maximum dimension, actinspecific fluorescence accumulated in the neck between the mother and the daughter (Fig. 1f).

Tubulin and actin rearrangement in mating cells

Zygote formation essentially followed the pattern outlined by Bilinski et al. (1975). Polarization of unbudded haploid cells was observed $1 \mathrm{~h}$ after mixing the strains of opposite mating types; the first zygotes appeared $1 \mathrm{~h}$ later.

Morphogenetic events stimulated by the action of pheromones promoted polarization of haploids (Fig. $2 a$ ) and a profound spatial reorganization of their interior. This included the 

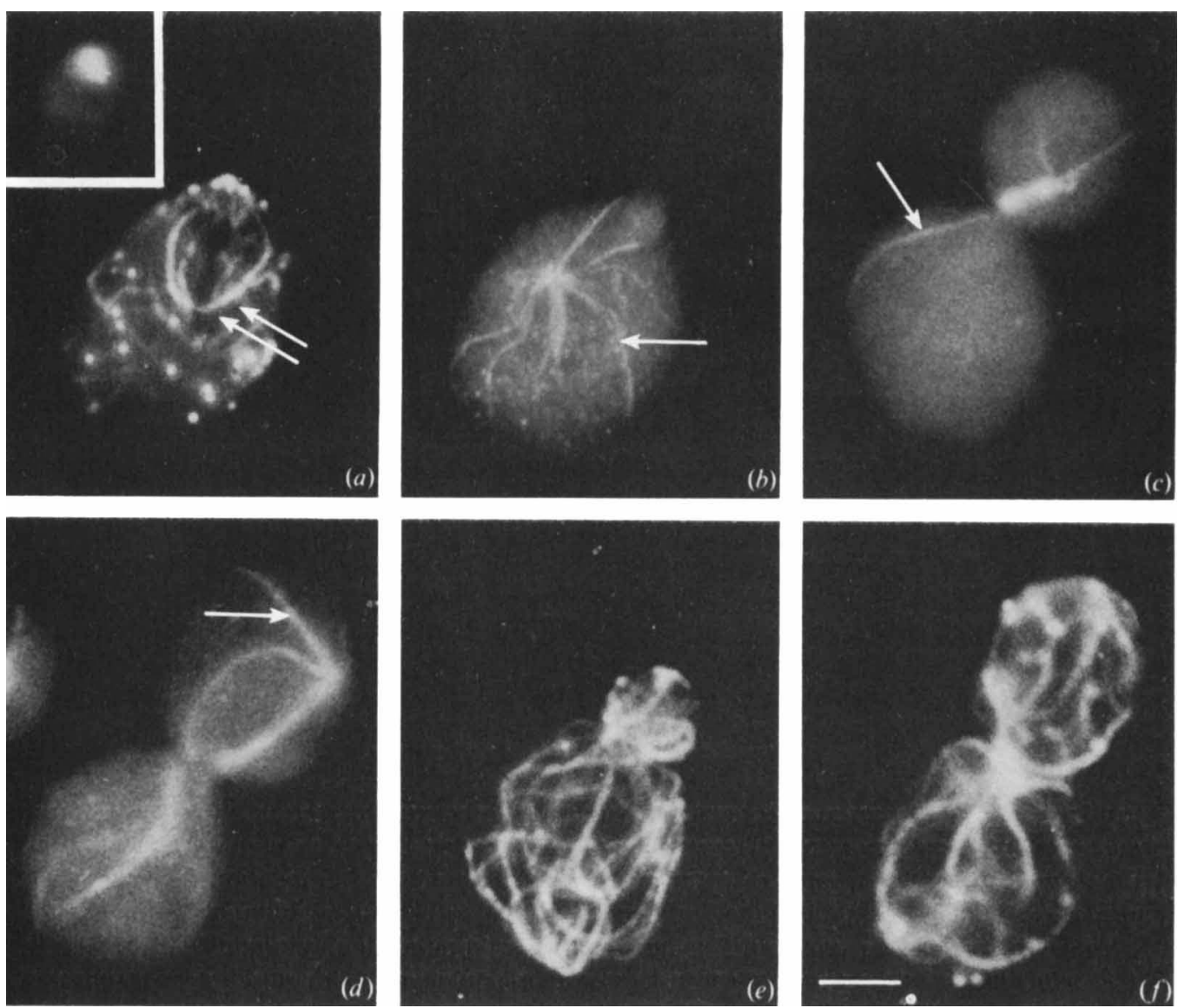

Fig. 1. S cerevisiae cell cycle configurations of F-actin labelled with rhodamine-conjugated phalloidin $(a, e, f)$ and of microtubules stained with monoclonal anti-tubulin antibody Tu01 $(b, c, d)$. Inset represents simultaneous DAPI-stained DNA of the same cell. Arrows indicate cytoplasmic microtubules; double arrow shows F-actin around the nucleus. Bar, $3 \mu \mathrm{m}$.

migration of the nucleus with its SPB-associated cytoplasmic microtubules toward the cell apex (Fig. $2 b$ ) and an accumulation of actin dots with accompanying filaments in the corresponding region (Fig. $2 c$ ).

Prior to mating, polarized cells of opposite mating types contacted each other through cell wall protuberances (Fig. $2 d$ ). As ascertained by DAPI staining, at the stage of intimate contact between $\alpha$ and a cells haploid nuclei were polarized and spatially oriented face to face (Fig. $2 e$ ). Cytoplasmic microtubules, apparently functional during fusion events in mating, were discerned in the contact area (not shown). Similarly, actin staining was accumulated in a dot-like manner in the contact area at all stages of zygote formation (Fig. $2 f$ ).

Fusion of $\alpha$ and a cells established cytoplasmic continuity and led to contact of the bundled cytoplasmic microtubules of both haploids in the neck of the zygote (Fig. $2 g$ ). Shortening of the cytoplasmic microtubules permitted the association of haploid SPBs (Fig. $2 h$ ) followed by karyogamy. Simultaneously, other cytoplasmic microtubules extended from the haploid SPBs into both halves of the zygote. At this stage, the actin pattern consisted of dots as well as of filaments: the dots were concentrated in the isthmus of the zygote with the filaments extended toward the periphery (Fig. 2i).

As zygotes accomplished karyogamy, strands of cytoplasmic microtubules were generally seen extending from a distinct point of the centred diploid nucleus (presumably the duplicated 

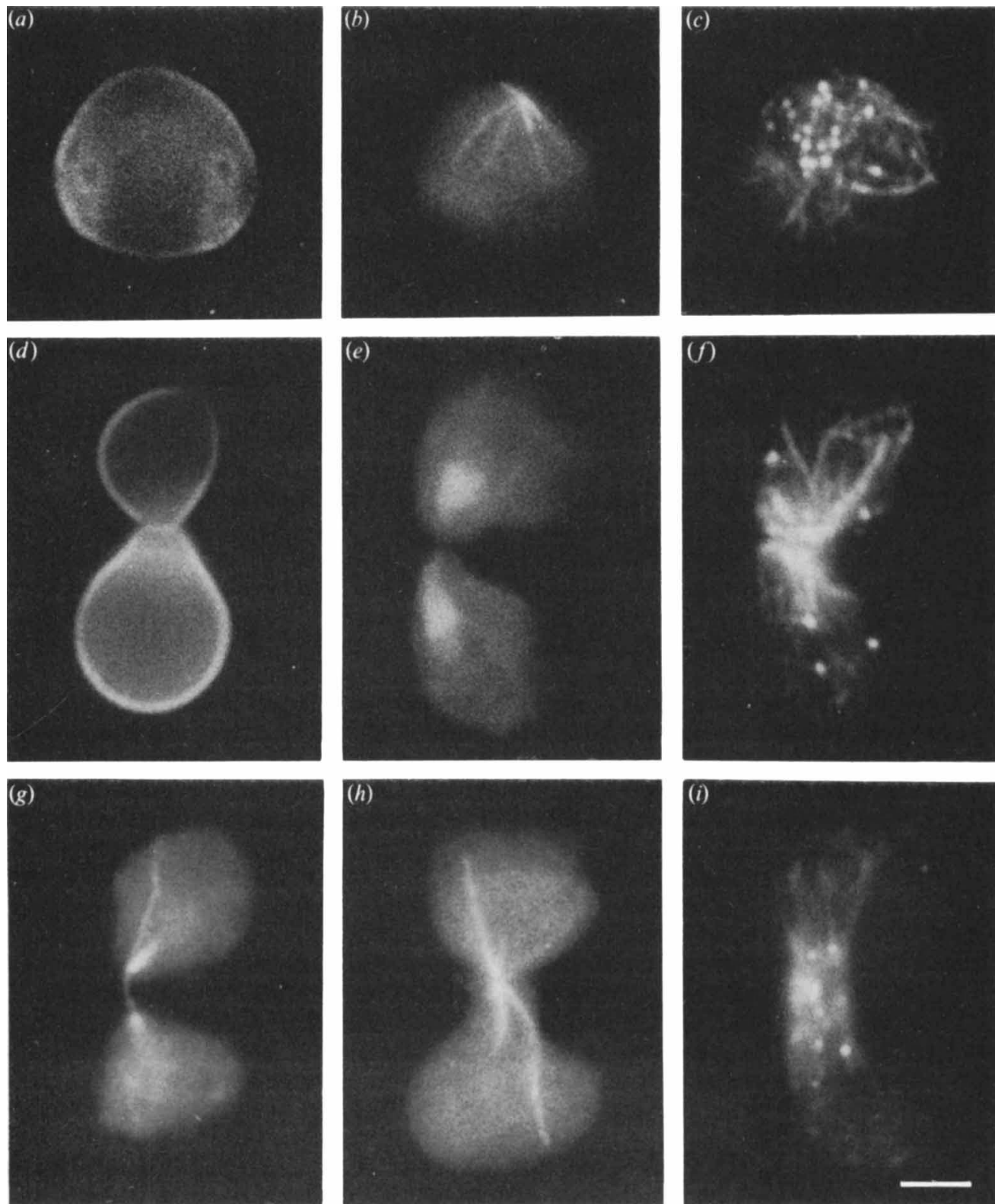

Fig. 2. Polarization of cell shape and cell interior of $S$. cerevisiae mating cells: $(a, d)$ primulin staining; $(b, g, h)$ immunofluorescence with anti-tubulin antibody Tu01; $(c, f, i) \mathrm{F}$-actin labelled with rhodamineconjugated phalloidin; (e) DAPI staining of DNA. Bar, $3 \mu \mathrm{m}$.

SPB) deeply into both halves of the zygote (Fig. $3 a$ ). Actin dots were straggled over the isthmus whereas the bundled actin was located throughout the cytoplasm. After nuclear fusion, formation of the first zygotic bud started typically in the isthmus of the zygote. Diploid buds forming on the zygote revealed essentially the same tubulin and actin patterns as those seen during the vegetative budding process. In small buds the cytoplasmic microtubules were directed towards the tips of growing daughter-cells (Fig. $3 b$ ) and the actin dots became translocated from the base of the bud to the expanding region. During mitosis one pole of the 

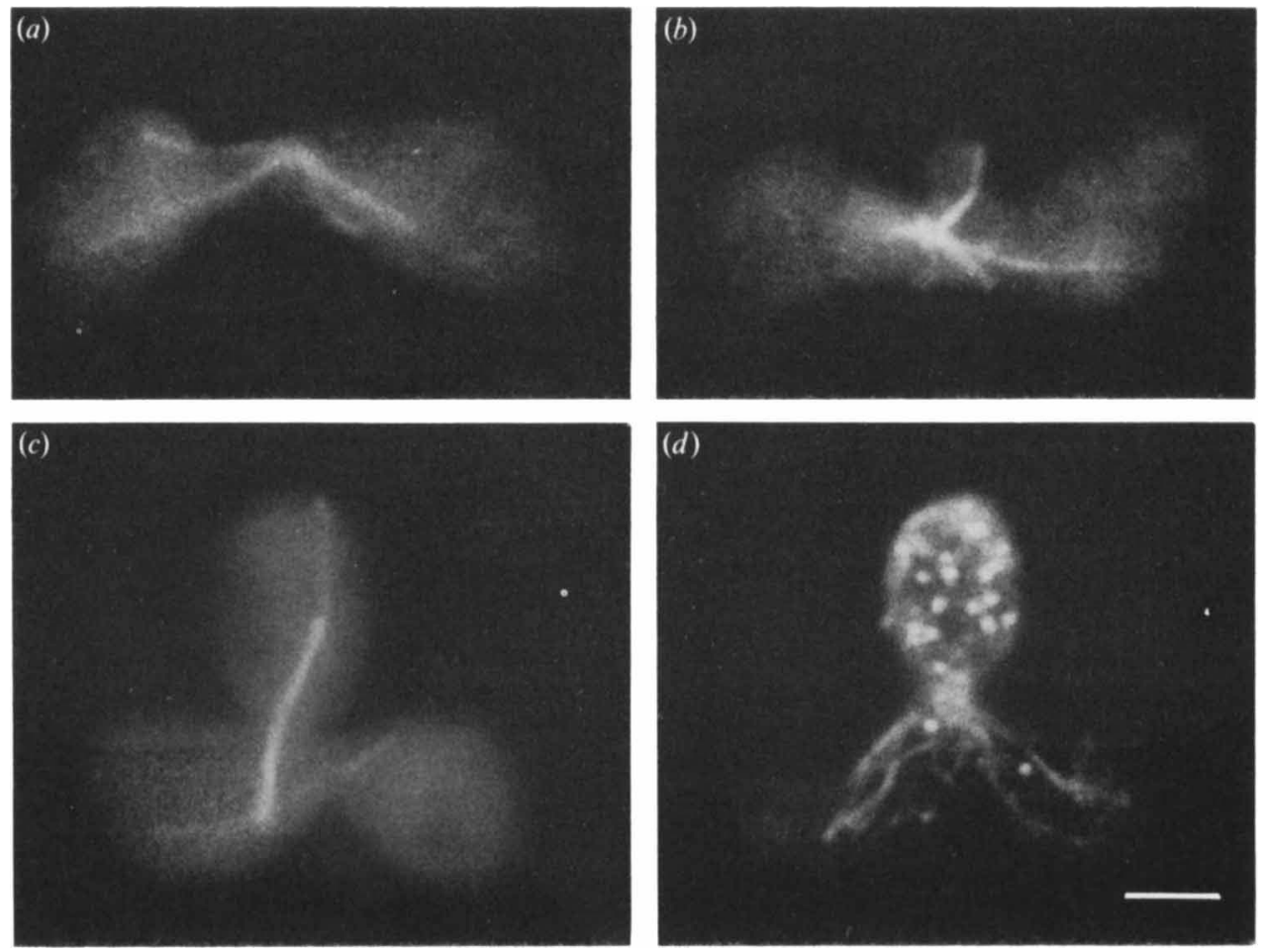

Fig. 3. Zygotes of $S$. cerevisiae: $(a, b, c)$ microtubular system labelled with anti-tubulin antibody Tu01; (d) labelling of F-actin with thodamine-conjugated phalloidin. Bar, $3 \mu \mathrm{m}$.

elongating spindle was guided by cytoplasmic microtubules into the diploid bud, whereas the opposite pole of the spindle, remaining anchored within the zygote, typically sent a bundled strand of cytoplasmic microtubules into each half of the zygote (Fig. $3 c$ ). In all cases noted, the growing buds were full of actin dots whereas the zygotes displayed predominantly cables of actin filaments (Fig. $3 d$ ). Prior to the separation of the bud a ring of actin was observed in the neck as in the vegetative cell division cycle.

\section{Effect of nocodazole on the conjugation process}

In general, the action of nocodazole did not unambiguously affect the individual steps of the conjugatory process, namely, agglutination, polarization of preconjugatory cells, zygote formation and budding. Cells of opposite mating types mixed in the presence of nocodazole $\left(10 \mu \mathrm{g} \mathrm{ml}^{-1}\right)$ and examined after $4 \mathrm{~h}$ consisted of 'shmoos', doubled cells and budding zygotes mostly arrested with large unpolarized first buds at the zygote isthmus. Even pretreatment of haploid cells with nocodazole for $1 \mathrm{~h}$ prior to mixing did not prevent polarization of preconjugatory cells and efficient fusion.

The drug-affected shmoos displayed depolymerized microtubules seen as punctate fluorescence without distinct microtubule profiles (Fig. $4 a$ ). Nuclei were not oriented apically. In marked contrast, actin dots with accompanying filaments were found to be clustered at the tips of shmoo-shaped cells (Fig. $4 b$ ). In zygotes no microtubules could be discerned in the fluorescence image (Fig. 4c) and nuclei were mostly positioned randomly (Fig. 4d). Actin granules were distributed throughout the cytoplasm in a fashion similar to untreated zygotes.

Zygotes terminated development as triplets consisting of the original dumb-bell-shaped zygote and a large unpolarized bug. Typically, two randomly positioned quiescent nuclei were 

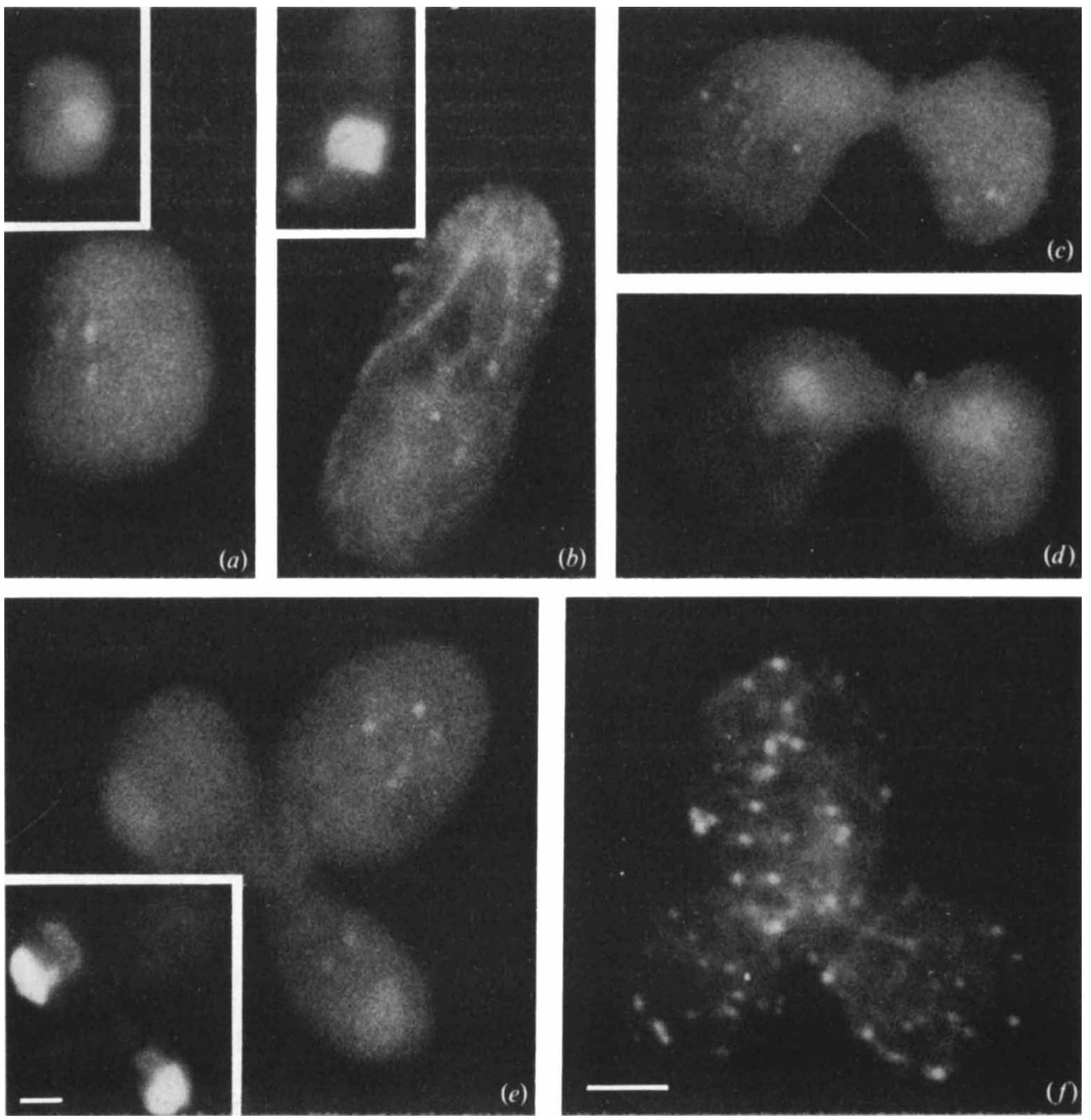

Fig. 4. Effect of a $4 \mathrm{~h}$ nocodazole treatment on mating cells of $S$. cerevisiae: $(a, c, e)$ depolymerized microtubules labelled with anti-tubulin antibody Tu01: $(b, f)$ staining with rhodamine-conjugated phalloidin for F-actin: insets and $(d)$ represent DAPI-stained DNA pattern of appropriate cells. Bars, $3 \mu \mathrm{m}$.

seen, each in one half of the zygote, the zygotic bud containing none. The microtubule cytoskeleton was effectively disrupted by the drug, leaving dimly stained spots of tubulin around the nuclei as well as in the unpolarized bud (Fig. $4 e$ ). The actin dots were uniformly scattered in the submembrane region of the triplets (Fig. $4 f$ ).

\section{DISCLSSION}

The deployment of tubulin and actin structures in preconjugatory haploids of $S$. cerevisiae is of particular interest. Since the ability to mate involves intercellular signalling (e.g. Davis \& Thorner, 1986), a choreographed reorganization of the cytoskeleton is apparently instrumental in the system of cellular response to diffusible mating pheromones. The location of future fusion sites occurs essentially randomly in relation to the longitudinal axes of the mating partners (Ford \& Pringle, 1986) and seems to be controlled by a set of cytoplasmic microtubules seen by electron 
microscopy (Byers \& Goetsch, 1974, 1975). These microtubules could be preferentially stabilized near the cell tips (Kirschner \& Mitchison, 1985) in response to a local gradient of diffusible pheromones secreted by competent cells into the medium (Herskowitz, 1986).

In zygotes, besides the pattern of cytoplasmic microtubules emanating from the SPBs of both mating partners into the zygotic isthmus established by electron microscopy (Byers \& Goetsch, $1974,1975)$ and documented in our pictures, additional cytoplasmic microtubule arrays organized by the SPBs were seen to extend into the cytoplasm of the former haploids facilitating spatial communication of the fusing nuclei with the periphery of the zygote. These microtubules are favourably deployed to exert influence on the preconjugatory movement of the nuclei and their alignment in karyogamy.

Following diploidization, the zygote starts diploid budding. The change in ploidy is reflected by the size of bud scars which arise on the zygote after separation of diploid buds. Thus, the fate of the diploid nucleus within the zygote may be monitored by the patterns of large diploid scars on the surface of the zygote (Streiblová, 1970, 1983). The unique location of diploid scars around the zygotic isthmus indicates a slight rotational movement of the postkaryogamy nucleus with SPB-associated microtubules in the narrow conjugational canal of the zygote in association with selection of new budding sites. If one considers this nuclear behaviour, the pronounced accumulation of actin in the isthmus of young zygotes cannot be completely ignored.

Detailed images of budding zygotes (and vegetative cells) suggest unequal spatial communication of cytoplasmic microtubules emanating from the paired SPB with the budding site and the remaining cytoplasm. This pattern can be interpreted as an indication for a functional specialization of the 'old' and 'new' SPB, one deploying its respective cytoplasmic microtubules predominantly into the growing bud whereas the other serves to organize the microtubular system within the mother-cell or zygote. Given the fact that the asymmetric mode of cellular replication substantially precedes nuclear division (Byers, 1981), the daughter SPBs may well be different in their microtubule organizing activity and thus specialized in morphogenetic functions during the entire cell cycle. Speculations about the functional specialization of daughter SPBs have been already presented (Thomas \& Botstein, 1986, Schmitt et al., 1986).

Application of nocodazole to mating cells led to a rapid and unequivocal disturbance of nuclear migration and zygotic nuclear fusion caused by the destruction of the associated microtubular system. Taken together with earlier observations indicating that nuclear fusion in zygotes is microtubule mediated (Byers \& Goetsch, 1974, 1975; Thomas et al., 1985; Rose \& Fink, 1985) and MBC-sensitive (Delgado \& Conde, 1984), these data strongly support a direct role for cytoplasmic microtubules in the general spatial control of the yeast nucleus.

On the other hand, nocodazole did not perturb the polarization of a and $\alpha$ cells and the occurrence of cell fusion. Importantly, the organization of actin dots and cables appeared to be established regardless of the absence of detectable microtubules. This seems to indicate that an actin-based system plays a prominent role in the hierarchy of spatial interrelationships during mating. One can speculate that actin is directly involved in the morphogenetic response to mating pheromones by controlling the machinery responsible for cell wall dissolution at the contact sites and for effective fusion of mating partners. Evidence for the involvement of actin in the movement of secretory vesicles, cell wall remodelling and growth is still accumulating (Kilmartin \& Adams, 1984; Adams \& Pringle, 1984; Novick \& Botstein, 1985; Marks \& Hyams, 1985; Marks et al., 1986; Anderson \& Soll, 1986; Pringle et al., 1986).

The terminal morphology of nocodazole-treated zygotes provided a striking instance of bud development in the absence of detectable microtubules. This phenomenon is commonly encountered in analyses of budding using MBC (Quinlan et al., 1980; Wood \& Hartwell, 1982) and nocodazole (Pringle et al., 1986). It should be stressed that in drug-treated zygotes bud emergence occurs at a predictable site on the zygote isthmus without a preceding fusion of haploid nuclei and thus without duplication of the conjugational SPB as has also been reported for MBC-treated zygotes (Delgado \& Conde, 1984) and confirmed by genetic experiments (Fink \& Conde, 1976; Conde \& Fink, 1976; Polaina \& Conde, 1982; Dutcher \& Hartwell, 1983; Rose $\&$ Fink, 1985). The fact that in the above situation the bud is established is an indication of some 
form of signalling additional to that suggested for cytokinesis (Girbardt, 1979; Streiblová, 1981), in which cytoplasmic microtubules are likely to assist in the positioning of the septum using a mechanism similar to furrowing that closely resembles cleavage in animal cells (Rappaport, 1986). This suggestion is supported by the absence of cytokinesis in nocodazole-treated cells and zygotes.

Although it is still largely unknown what signals determine the positioning of buds under normal conditions, our observation of drug-treated zygotes leads to the conclusion that it is highly unlikely that two randomly positioned nuclei could, under the given geometrical relations, impart signals culminating in bud emergence at the predicted site of the zygote isthmus. It thus seems expedient to study the possible interactions occurring at the periphery of the zygote. Bud emergence at the isthmus could be elicited by budding-related activities induced at the tips of preconjugatory cells by local gradients of mating pheromones prior to fusion. Supporting evidence for this assumption comes from investigations of vegetative cells growing in the presence of subinhibitory concentrations of $\alpha$-factor (Herskowitz, 1986). In these cells, a budding-related activity is induced at the point closest to the $\alpha$-factor source resulting in bud formation at that point irrespective of the original cell axis.

\section{REFERENCES}

Adams, A. E. M. \& Pringle, J. R. (1984). Relationship of actin and tubulin distribution to bud growth in wild-type and morphogenetic mutant Saccharomyces cerecisiae. Journal of Cell Biology 98, 935-945.

ANDERSON, J. M. \& SolL, D. R. (1986). Difference in actin localization during bud and hypha formation in the yeast Candida albicans. Journal of General Microbiology 132, 2035-2047.

BILINSKI, T., LitwinsKa, J., ZUK, J. \& Gajewski, W. (1975). Synchronous zygote formation in yeast. Methods in Cell Biology 11, 89-96.

Byers, B. (1981). Cytology of the yeast life cycle. In The Molecular Biology of the Yeast Saccharomyces: Life Cycle and Inheritance, pp. 59-96. Edited by J. N. Strathern, E. W. Jones \& J. R. Broach. Cold Spring Harbor NY: Cold Spring Harbor Laboratory.

Byers, B. \& GoETSCH, L. (1974). Duplication of spindle plaques and integration of the yeast cell cycle. Cold Spring Harbor Symposia on Quantitative Biology 38, 123-131.

Byers, B. \& GoetsCh, L. (1975). Behavior of spindles and spindle plaques in the cell cycle and conjugation of Saccharomyces cerevisiae. Journal of Bacteriology' 124. $511-523$.

CONDE, J. \& FINK, G. R. (1976). A mutant of Saccharomyces cerecisiae defective in nuclear fusion. Proceedings of the National Academy of Sciences of the United States of America 73, 3651-3655.

Davis, T. N. \& Thorner, J. (1986). Calmodulin and other calcium-binding proteins in yeast. In Yeast Cell Biology, pp. 477-503. Edited by J. Hicks. New York: Alan R. Liss.

Delgado, M. A. \& Conde, J. (1984). Benomyl prevents nuclear fusion in Saccharomyces cerevisiae. Molecular and General Genetics 193, 188-189.

Dráber, P., Rubino. S., Dráberová, E., Viklický, V. \& CappuCinelli, P. (1985). A broad spectrum monoclonal antibody to alpha-tubulin does not recognize all protozoan tubulins. Protoplasma 128, 201-207.

DUtCher, S. K. \& HARTwell, L. H. (1983). Genes that act before conjugation to prepare the Saccharomyces cerevisiae nucleus for caryogamy. Cell 33, 203210.
Fink, G. R. (1970). The biochemical genetics of yeast. Methods in Enzymology 17, 59-78.

FINK, G. R. \& CONDE, J. (1976). Studies on KARI, a gene required for nuclear fusion in yeast. In International Cell Biology, pp. 414-419. Edited by B. R. Brinkley \& K. R. Porter. New York: Rockefeller University Press.

Ford, S. \& Pringle, J. R. (1986). Development of spatial organization during the formation of zygotes and shmoos in Saccharomyces cerevisiae. 13th International Conference on Yeast Genetics and Molecular Biology S114.

Giloh, H. J. \& Sedat, J. W. (1982). Fluorescence microscopy: reduced photobleaching of rhodamine and fluorescein protein conjugates by n-propyl gallate. Science 217, 1252-1255.

GIRBARDT, M. (1979). A microfilamentous septal belt (FSP) during induction of cytokinesis in Trametes versicolor (L. ex Fr.). Experimental Mycology 3, 215228.

HarTwell, L. H. (1973). Synchronization of haploid yeast cell cycles, a prelude to conjugation. Experimental Cell Research 76, 111-117.

Hašek, J., Svobodová, J. \& Streiblová, E. (1986). Immunofluorescence of the microtubular skeleton in growing and drug-treated yeast protoplasts. European Journal of Cell Biology 41, 150-156.

HeRsKowItz, I. (1986). Specialized cell types in yeast: their use in addressing problems in cell biology. In Yeast Cell Biology, pp. 625-656. Edited by J. Hicks. New York: Alan R. Liss.

Hoebeke, J., Van Nijen, G. \& De Brabander, M. (1976). Interaction of nocodazole (R17934), a new antitumoral drug, with rat brain tubulin. Biochemical and Biophysical Research Communications 69, 319 324.

Johnson, G. D. \& de C. Nogueira Araujo, G. M. (1981). A simple method of reducing the fading of immunofluorescence during microscopy. Journal of Immunological Methods 43, 349-350.

Kilmartin, J. V. \& Adams, A. E. M. (1984). Structural rearrangements of tubulin and actin during the cell cycle of the yeast Saccharomyces. Journal of Cell Biology 98, 922-933. 
Kirschner, M. \& Mitchison, T. (1986). Beyond selfassembly: from microtubes to morphogenesis. Cell 45, 329-342.

MARKs, J. \& Hyams, J. S. (1985). Localization of Factin through the cell division cycle of Schizosaccharomyces pombe. European Journal of Cell Biology, 39, 27-32.

Marks, J., Hagan, I. M. \& Hyams, J. S. (1986). Growth polarity and cytokinesis in fission yeast: the role of the cytoskeleton. Journal of Cell Science, 80-86 suppl. 5, 229-241.

Novick, P. \& Botstein, D. (1985). Phenotypic analysis of temperature-sensitive yeast actin mutants. Cell $\mathbf{4 0}$, 405-416.

Pillus, L. \& Solomon, F. (1986). Components of microtubular structures in Saccharomyces cerevisiae. Proceedings of the National Academy of Sciences of the United States of America 83, 2468-2472.

Polaina, J. \& Conde, J. (1982). Genes involved in the control of nuclear fusion during the sexual cycle of Saccharomyces cerevisiae. Molecular and General Genetics 186, 253-258.

Pringle, J. R., Lillie, S. H., Adams, A. E. M., Jacobs, C. W., HaArer, B. K., Coleman, K. G., Robinson, J. S., Bloom, L. \& Preston, R. A. (1986). Cellular morphogenesis in the yeast cell cycle. In Yeast Cell Biology, pp. 193-209. Edited by J. Hicks. New York: Alan R. Liss.

Quinlan, R. A., Pogson, C. I. \& Gull, K. (1980). The influence of the microtubule inhibitor, methylbenzimidazol-2-yl-carbamate (MBC) on nuclear division and the cell cycle in Saccharomyces cerevisiae. Journal of Cell Science 46, 341-352.

RAPPAPORT, R. (1986). Mitotic apparatus-surface interaction and cell division. International Journal of Invertebrate Reproduction and Development 9, 263277.

Rose, M. D. \& FinK, G. R. (1985). Nuclear fusion in yeast. Journal of Cell Biochemistry 90, 116.
Streibloví, E. (1970). Study of scar formation in the life cycle of heterothallic Saccharomyces cerevisiae. Canadian Journal of Microbiology 16, 827-831.

Streiblová, E. (1981). Fission. In Yeast Cell Envelopes: Biochemistry, Biophysics and Ultrastructure, vol. 2, pp. 80-92. Boca Raton, Fla.: CRC Press.

STREIBLOVÁ, E. (1983). The yeast cell wall - a marker system for cell cycle controls. In The Microbial Cell Cycle, pp. 127-141. Edited by P. Nurse \& E. Streiblová. Boca Raton, Fla.: CRC Press.

Thomas, J. H., NefF, P. \& Botstein, D. (1985). Isolation and characterization of mutations in betatubulin gene of Saccharomyces cerevisiae. Genetics 112, 715-734.

Thomas, J. H. \& Botstein, D. (1986). A gene required for the separation of chromosomes on the spindle apparatus in yeast. Cell 44, 65-76.

THORNER, J. (1981). Pheromonal regulation of development in Saccharomyces cerevisiae. In The Molecular Biology of the Yeast Saccharomyces: Life Cycle and Inheritance, pp. 143-180. Edited by J. N. Strathern, E. W. Jones \& J. R. Broach. Cold Spring Harbor, NY: Cold Spring Harbor Laboratory.

VIKLICKÝ, V., DrÁBER, P., HAŠEK, J. \& BÁRTEK, J. (1982). Production and characterization of a monoclonal antitubulin antibody. Cell Biology International Reports 6, 726-731.

Wieland, Th. \& Govindan, V. M. (1974). Phallotoxins bind to actins. FEBS Letters 46, 315-353.

Williamson, D. H. \& FenNEL, D. H. (1975). The use of fluorescent DNA binding agent for detecting and separating yeast mitochondrial DNA. Methods in Cell Biology 12, 335-351.

WoOd, J. S. \& HarTwell, L. H. (1982). A dependent pathway of gene functions leading to chromosome segregation in Saccharomyces cerevisiae. Journal of Cell Biology 94, 718-726. 